Journal of Management and Bussines (JOMB)

Volume 2, Nomor 2, Desember 2020

$p-I S S N$ : 2656-8918

e-ISSN:2684-8317

DOI : https://doi.org/10.31539/jomb.v2i2.1847

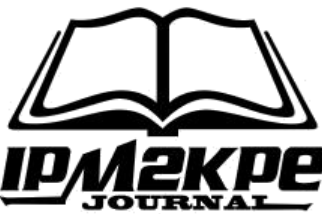

\title{
LOYALITAS PELANGGAN BERDASARKAN KUALITAS PELAYANAN DAN KEPUASAN PELANGGAN
}

\author{
Hayani \\ Sekolah Tinggi Ilmu Ekonomi Serelo Lahat \\ hayani2020123@gmail.com
}

\begin{abstract}
ABSTRAK
Tujuan penelitian ini adalah untuk mengetahui pengaruh kualitas pelayanan dan kepuasan pelanggan terhadap loyalitas pelanggan Percetakan Sobat Lahat. Metode yang digunakan pada penelitian ini yaitu metode desktriptif dengan pendekatan kuantitatif. Sampel dalam penelitian ini berjumlah 60 responden yang disebar secara acak kepada pelanggan Percetakan Sobat Lahat. Hasil penelitian menunjukkan bahwa nilai koefisien kualitas pelayanan adalah 0,273 dan kepuasan pelanggan sebesar 0,612. Simpulan, kualitas pelayanan dan kepuasan pelanggan berpengaruh signifikan terhadap loyalitas pelanggan. Namun, variabel kepuasan pelanggan bersifat paling dominan berpengaruh terhadap loyalitas pelanggan pada Percetakan Sobat Lahat.
\end{abstract}

Kata Kunci: Loyalitas Pelanggan, Kepuasan Pelanggan, Kualitas Pelayanan

\section{ABSTRACT}

The purpose of this study was to determine the effect of service quality and customer satisfaction on customer loyalty of Sobat Lahat Printing. The method used in this research is descriptive method with a quantitative approach. The sample in this study amounted to 60 respondents who were distributed randomly to the Sobat Lahat Printing customer. The results showed that the service quality coefficient value was 0.273 and customer satisfaction was 0.612. In conclusion, service quality and customer satisfaction have a significant effect on customer loyalty. However, the customer satisfaction variable has the most dominant influence on customer loyalty at the Sobat Lahat Printing.

Keywords: Customer Loyalty, Customer Satisfaction, Service Quality

\section{PENDAHULUAN}

Saat ini perkembangan teknologi semakin berkembang, bisnis percetakan di Indonesia yang menggunakan mesin-mesin digital ataupun offset terus bertambah. Bisnis percetakan merupakan salah satu suatu jenis usaha yang mulai diperhitungkan keberadaannya, terutama dalam beberapa tahun terakhir ini, bisnis percetakan semakin berkembang dengan pesat. Hal ini dapat dilihat dari munculnya pelaku-pelaku usaha baru dalam bisnis ini, salah satunya adalah Percetakan Sobat Lahat.

Usaha percetakan tidak terlepas dari hasil-hasil media yang telah dihasilkan oleh percetakan yang ada, seperti spanduk, brosur, panflet, poster, buku dan masih banyak 
lagi. Namun setiap usaha percetakan tidak selalu berjalan dengan mulus dan lancar. Tentunya akan ada permasalahan yang harus diselesaikan dan tantangan yang harus dihadapi, diantaranya masih banyak pelanggan yang berpindah menggunakan jasa percetakan lain, sedikit saja ada isu negatif tentang percetakan tersebut pelanggan langsung berpindah ke percetakan lain dan terkadang keberadaan percetakan belum diakui sepenuhnya atau secara menyeluruh oleh pelanggan. Begitu juga dengan Percetakan Sobat Lahat, masalah-masalah seperti itu tentunya pernah dialami oleh Percetakan tersebut. Hal ini berkenaan dengan bagaimana usaha percetakan bisa memberikan pelayanan yang baik dan membuat pelanggan puas dengan hasil percetakan sehingga pelanggan loyal kepada percetakan tersebut.

Usaha percetakan merupakan usaha yang paling dibutuhkan oleh banyak orang dikarenakan fungsinya yang sangat dibutuhkan dalam kehidupan sehari-hari. Setiap harinya, ribuan sampai jutaan bahan cetak diproduksi. Biasanya hasil cetak dari bisnis percetakan digunakan sebagai alat untuk memberikan informasi kepada khalayak mengenai sebuah event, pengetahuan dan sesuatu yang ingin diinformasikan pada masyarakat luas.

Loyalitas pelanggan menjadi salah satu faktor paling penting dalam kemajuan suatu usaha karena dapat menunjang pendapatan dari usaha tersebut. Menurut Hasan (2015) loyalitas pelanggan adalah pelanggan yang tidak hanya membeli ulang suatu barang dan jasa, tetapi juga merekomendasikannya kepada orang lain untuk membeli. Loyalitas dapat dipengaruhi oleh kualitas pelayanan. Menurut Kotler (2013) kualitas pelayanan merupakan totalitas dari bentuk karakteristik barang dan jasa yang menunjukkan kemampuannya untuk memuaskan kebutuhan pelanggan, baik yang terlihat jelas maupun yang tersembunyi. Bagi perusahaan yang bergerak di sektor jasa, pemberian pelayanan yang berkualitas pada pelanggan merupakan hal mutlak yang harus dilakukan apabila perusahaan ingin mencapai keberhasilan. Kemudian faktor lain yang bisa berpengaruh pada loyalitas pelanggan yaitu kepuasan pelanggan. Menurut Tjiptono \& Chandra (2012) kepuasan atau ketidakpuasan pelanggan adalah respon pelanggan terhadap evaluasi ketidaksesuaian (disconfirmation) yang dirasakan antara harapan sebelumnya. Berdasarkan uraian tersebut, maka penulis tertarik melakukan penelitian di Percetakan Sobat Lahat untuk mengkaji pengaruh kualitas pelayanan dan kepuasan pelanggan terhadap loyalitas pelanggan pada Percetakan Sobat Lahat. 


\section{KAJIAN TEORI}

\section{Pengertian Pemasaran}

Menurut Kotler \& Keller (2016) pemasaran adalah suatu proses sosial yang di dalamnya terdapat individu dan kelompok yang memperoleh kebutuhan dan keinginan mereka dengan menciptakan, menawarkan dan secara bebas dapat mempertukarkan produk yang bernilai dengan pihak lain. Hal ini menunjukkan bahwa keinginan konsumen harus dipuaskan secara efektif agar pemasaran berhasil. Oleh karena itu, perusahaan harus memaksimalkan penjualan agar dapat menghasilkan laba dalam jangka panjang.

\section{Pengertian Kualitas Pelayanan}

Kata kualitas mengandung banyak definisi dan makna karena orang yang berbeda akan mengartikannya secara berlainan, seperti kesesuaian dengan persyaratan atau tuntutan, kecocokan untuk pemakaian, bebas dari kerusakan atau cacat, pemenuhan kebutuhan pelanggan dan melakukan segala sesuatu yang membahagiakan.

Menurut Tjiptono (2015) kualitas pelayanan secara sederhana adalah ukuran seberapa bagus tingkat layanan yang diberikan agar mampu sesuai dengan harapan pelanggan. Artinya kualitas pelayanan ditentukan oleh kemampuan perusahaan atau lembaga tertentu untuk memenuhi kebutuhan yang sesuai dengan harapan atau keinginan berdasarkan kebutuhan pelanggan/pengunjung.

Indikator kualitas pelayanan menurut Lupiyoadi (2013) adalah: 1) bukti fisik (tangible), bukti nyata dari pelayanan yang diberikan oleh pemberi jasa adalah penampilan dan kemampuan sarana ataupun prasarana yang dimiliki oleh perusahaan serta keadaan lingkungan sekitarnya. Dalam hal ini perusahaan harus mampu secara nyata menunjukkan kelebihan mereka seperti fasilitas gedung perkantoran, layout ruangan, penampilan pegawainya dan penunjang lainnya; 2) keandalan (reliability), kemampuan perusahaan dalam memberikan pelayanan secara akurat dan terpercaya sesuai dengan yang dijanjikan. Hal ini dapat meliputi ketepatan melayani, tidak ceroboh dan akurat. Kinerja yang diberikan oleh pemberi jasa harus sesuai dengan harapan pelanggan yang telah disepakati bersama.

Selanjutnya, 3) daya tanggap (responsiveness), kebijakan untuk membantu dan memberikan pelayanan yang cepat dan tepat kepada pelanggan; 4) jaminan (assurance), 
pengetahuan, kesopansantunan dan kemampuan pegawai perusahaan dalam menumbuhkan kepercayaan yang tinggi dan tidak ragu-ragu terhadap perusahaan; 5) empati (empathy), kemampuan perusahaan memberikan perhatian yang tulus dan bersifat individual atau pribadi kepada para pelanggan dengan harapan dapat mengetahui segala keinginan dan kebutuhan konsumen.

\section{Pengertian Kepuasan Pelanggan}

Kepuasan (satisfaction) adalah perasaan senang atau kecewa seseorang yang muncul setelah membandingkan kinerja (hasil) produk yang dipikirkan terhadap kinerja (atau hasil) yang diharapkan. Jika kinerja berada di bawah harapan maka pelanggan tidak puas. Jika kinerja memenuhi harapan maka pelanggan puas. Jika kinerja melebihi harapan maka pelanggan amat puas atau senang (Kotler, 2013). Adapun menurut Tjiptono (2015) kepuasan pelanggan merupakan respon pelanggan terhadap evaluasi persepsi atas perbedaan antara harapan awal sebelum pembelian dan kinerja aktual produk setelah pelanggan memakai atau mengkonsumsi produk tersebut.

Menurut Tjiptono (2015) atribut pembentuk kepuasan terdiri dari: 1) kesesuaian harapan, merupakan tingkat kesesuaian antara kinerja produk yang diharapkan oleh pelanggan dengan yang dirasakan oleh pelanggan, meliputi produk yang diperoleh sesuai atau melebihi dengan yang diharapkan, pelayanan oleh karyawan yang diperoleh sesuai atau melebihi dengan yang diharapkan, fasilitas penunjang yang didapat sesuai atau melebihi dengan yang diharapkan; 2) minat berkunjung kembali, merupakan kesediaan pelanggan untuk berkunjung kembali atau melakukan pembelian ulang terhadap produk terkait, meliputi berminat untuk berkunjung kembali karena pelayanan yang diberikan oleh karyawan memuaskan, nilai dan manfaat yang diperoleh setelah mengkonsumsi produk dan fasilitas penunjang yang disediakan memadai; 3) kesediaan merekomendasikan, yaitu kesediaan pelanggan untuk merekomendasikan produk yang telah dirasakannya kepada teman atau keluarga.

\section{Pengertian Loyalitas Pelanggan}

Menurut Kotler \& Keller (2016) loyalitas merupakan komitmen yang dipegang secara mendalam untuk membeli kembali produk atau jasa yang disukai di masa depan meski pengaruh situasi dan usaha pemasaran berpotensi menyebabkan pelanggan 
beralih. Menurut Tjiptono \& Chandra (2012) loyalitas pelanggan adalah komitmen pelanggan terhadap suatu merek, toko atau pemasok berdasarkan sifat yang sangat positif dalam pembelian jangka panjang. Indikator yang digunakan untuk variabel loyalitas meliputi penggunaan ulang layanan, layanan di benak pelanggan tertanam secara positif dan selalu menjadi pilihan utama bagi pelanggan.

Loyalitas pelanggan sangat penting bagi perusahaan untuk menjaga kelangsungan kegiatan usahanya. Loyalitas pelanggan dapat dikelompokkan menjadi dua jenis, yaitu loyalitas merek (brand loyalty) dan loyalitas toko (store loyalty). Loyalitas merek adalah sikap menyenangi terhadap suatu merek yang direpresentasikan dalam pembelian yang konsisten terhadap merek itu sepanjang waktu, sedangkan loyalitas toko juga ditunjukkan oleh perilaku konsisten tetapi perilaku konsistennya adalah dengan mengunjungi toko dimana pelanggan tersebut bisa membeli merek yang diinginkan (Sutisna, 2012).

Indikator dari loyalitas pelanggan menurut Kotler \& Keller (2016) adalah kesetiaan terhadap pembelian produk (repeat purchase), ketahanan terhadap pengaruh yang negatif mengenai perusahaan (retention), mereferensikan secara total eksistensi perusahaan (referalls). Menurut Alma (2013) ada enam alasan mengapa perusahaan harus menjaga dan mempertahankan konsumennya, diantaranya yaitu: 1) pelanggan yang sudah ada memiliki prospek yang lebih besar untuk memberikan keuntungan kepada perusahaan; 2) biaya yang dikeluarkan perusahaan dalam menjaga dan mempertahankan pelanggan yang sudah ada, jauh lebih kecil daripada mencari pelanggan baru.

Selanjutnya, 3) pelanggan yang percaya kepada suatu lembaga dalam suatu urusan bisnis, cenderung akan percaya juga pada urusan bisnis yang lain; 4) jika sebuah perusahaan lama memiliki banyak pelanggan lama, maka perusahaan tersebut akan mendapatkan keuntungan karena adanya efisiensi; 5) pelanggan lama telah banyak memiliki pengalaman positif yang berhubungan dengan perusahaan, sehingga mengurangi biaya psikologis dan sosialisasi. Pelanggan lama akan berusaha membela perusahaan dan mereferensikan perusahaan tersebut kepada teman-teman maupun lingkungannya. 


\section{METODE PENELITIAN}

Penelitian ini menggunakan jenis penelitian desktriptif dengan pendekatan kuantitatif. Menurut Siregar (2013) penelitian deskritif adalah penelitian yang dilakukan untuk mengetahui nilai variabel mandiri, baik satu variabel atau lebih (independen) tanpa membuat perbandingan atau penghubungan dengan variabel yang lain. Adapun pendekatan kuantitatif adalah penelitian yang menggunakan data berupa angka-angka dan analisisnya dilakukan menggunakan statistik.

Populasi yang diteliti dalam penelitian ini adalah para pelanggan Percetakan Sobat Lahat sebanyak 150 orang. Menurut Arikunto (2012) jika subjeknya kurang dari 100 orang, maka diambil semuanya sebagai sampel. Namun jika subjeknya besar atau lebih dari 100 orang, maka dapat diambil 25\% atau lebih. Dengan demikian sampel yang diteliti dalam penelitian ini berjumlah 60 orang responden.

Sumber data yang digunakan pada penelitian ini adalah data primer dan data sekunder. Data primer merupakan data yang diperoleh atau dikumpulkan langsung di lapangan. Data primer didapat dengan cara menyebarkan kuesioner yang akan dirancang sesuai dengan varibel dan indikator serta item yang ditetapkan terlebih dahulu yang berkaitan dengan insentif serta prestasi kerja kepada responden. Adapun data sekunder merupakan data yang diperoleh melalui pengumpulan dokumen-dokumen yang telah ada pada instansi tempat dilakukannya penelitian berupa data-data bagian departemen sumber daya manusia, yang meliputi struktur organisasi, gambaran umum instansi, komposisi tenaga kerja serta bisa juga yang berasal dari literatur ataupun internet. Kemudian analisis pada penelitian ini menggunakan aplikasi SPSS 22.0.

\section{HASIL PENELITIAN}

\section{Analisis Regresi Linier Berganda}

Pengujian ini menggunakan analisis regresi berganda untuk mengetahui seberapa besar pengaruh variabel bebas (kualitas pelayanan dan kepuasan pelanggan) terhadap variabel terikat (loyalitas pelanggan). Adapun hasil uji analisis regresi berganda adalah sebagai berikut: 
Tabel 1.

Hasil Uji Regresi Linier Berganda

\begin{tabular}{|c|c|c|c|c|}
\hline \multicolumn{5}{|c|}{ Coefficients $^{a}$} \\
\hline & \multirow[b]{2}{*}{ Model } & \multicolumn{2}{|c|}{ Unstandardized Coefficients } & \multirow{2}{*}{$\begin{array}{c}\text { Standardized Coefficients } \\
\text { Beta }\end{array}$} \\
\hline & & $\mathrm{B}$ & Std. Error & \\
\hline \multirow{3}{*}{1} & $($ Constant $)$ & 3,514 & 2,237 & \\
\hline & Kualitas Pelayanan & 273 & ,099 & ,316 \\
\hline & Kepuasan Pelanggan & ,612 &, 115 & ,613 \\
\hline & lent Variable: Loyal & elanggar & & \\
\hline
\end{tabular}

Berdasarkan hasil yang telah diperoleh dari koefisien regresi diatas, maka dapat dibuat suatu persamaan regresi sebagai berikut:

$$
Y=3,514+0,273 X_{1}+0,612 X_{2}+e
$$

Persamaan tersebut menunjukkan bahwa koefisien dari kualitas pelayanan dan kepuasan pelanggan mempunyai pengaruh yang searah dengan loyalitas pelanggan, artinya variabel bebas tersebut mampu meningkatkan atau menurunkan loyalitas pelanggan. Dengan persamaan regresi yang telah didapat, dapat diartikan sebagai berikut: 1) nilai konstanta sebesar 3,514, nilai ini berarti bahwa variabel kualitas pelayanan dan kepuasan pelanggan tidak ada atau sebesar nol, maka nilai loyalitas pelanggan adalah sebesar 3,514 ; 2) nilai koefisien regresi untuk variabel kualitas pelayanan menunjukkan nilai positif sebesar 0,273, artinya jika kualitas pelayanan meningkat sedangkan kepuasan pelanggan tetap, maka loyalitas pelanggan meningkat sebesar 0,273; 3) nilai koefisien regresi untuk variabel kepuasan pelanggan menunjukkan nilai positif sebesar 0,612, artinya jika kepuasan pelanggan meningkat sedangkan kualitas pelayanan tetap maka loyallitas pelanggan meningkat sebesar 0,612.

\section{PEMBAHASAN}

Hasil penelitian ini menunjukkan bahwa kualitas pelayanan berpengaruh signifikan terhadap loyalitas pelanggan. Hal ini sejalan dengan hasil penelitian Apriyani \& Sunarti (2017) bahwa variabel kualitas pelayanan memberikan kontribusi terhadap kepuasan konsumen. Artinya kualitas pelayanan memiliki pengaruh yang signifikan terhadap kepuasan konsumen.

Nilai kualitas pelayanan sangat tergantung pada kemampuan instansi atau organisasi serta stafnya dalam memenuhi harapan pelanggan secara konsisten. Ciri-ciri pelayanan yang baik menurut Kasmir (2015) adalah sebagai berikut: 1) bertanggung 
jawab kepada setiap pelanggan sejak awal hingga selesai; 2) mampu melayani secara cepat dan tepat; 3) mampu berkomunikasi; 4) mampu memberikan jaminan kerahasiaan setiap transaksi; 5) memiliki pengetahuan dan kemampuan yang baik; 6) berusaha memahami kebutuhan pelanggan/pengunjung; 7) memberikan kepercayaan kepada pelanggan/pengunjung.

Kualitas pelayanan pada prinsipnya adalah menjaga janji pelanggan agar pihak yang dilayani terus merasa puas dan diungkapkannya melalui ucapan. Kualitas memiliki hubungan yang sangat erat dengan loyalitas pelanggan, yaitu kualitas memberikan suatu dorongan kepada pelanggan untuk menjalani ikatan hubungan yang kuat dengan organisasi pemberi layanan. Ikatan hubungan yang baik akan memungkinkan lembaga pelayanan jasa untuk memahami dengan seksama harapan pelanggan serta kebutuhan mereka (Apriyanti, 2019).

Hasil penelitian ini juga menunjukkan bahwa kepuasan pelanggan berpengaruh signifikan terhadap loyalitas pelanggan. Hasil ini didukung oleh temuan Nurhidayati \& Yuliantari (2018) bahwa terdapat pengaruh yang kuat antara kepuasan pelanggan dan loyalitas pelanggan. Menurut Rachmawati (2014) semakin konsumen puas terhadap suatu produk atau terpuaskan antara harapan dengan kenyataannya, maka hal tersebut akan meyebabkan konsumen kembali lagi untuk membeli produk tersebut dan menjadi konsumen yang loyal terhadap produk penjual.

Kepuasan konsumen dapat diciptakan melalui kualitas, pelayanan dan nilai. Kunci untuk menghasikan kesetian pelanggan adalah dengan memberikan nilai pelanggan yang tinggi. Menurut Kotler \& Armstrong (2016), nilai pelanggan adalah perbandingan pelanggan diantara semua keuntungan dan semua biaya yang harus dikeluarkan untuk menerima penawaran yang diberikan. Apabila pelanggan mendapatkan kepuasaan, mereka akan meningkatkan loyalitas mereka sehingga penyedia produk memperoleh keuntungan.

\section{SIMPULAN}

Kualitas pelayanan dan kepuasan pelanggan berpengaruh signifikan terhadap loyalitas pelanggan. Namun, variabel kepuasan pelanggan bersifat paling dominan berpengaruh terhadap loyalitas pelanggan pada Percetakan Sobat Lahat. Hal ini terlihat dari nilai koefisien regresinya yang paling besar. 


\section{DAFTAR PUSTAKA}

Alma, B. (2013). Manajemen Pemasaran dan Pemasaran Jasa, Cetakan Kedelapan, Bandung: Alfabeta

Apriyani, D. A., \& Sunarti, S. (2017). Pengaruh Kualitas Pelayanan terhadap Kepuasan Konsumen (Survei pada Konsumen The Little A Coffee Shop Sidoarjo). EJurnal Administrasi Bisnis (JAB), 51(2), 1-7

Apriyanti, M. D. (2019). Analisis Kualitas Pelayanan Pemberian Kredit terhadap Kepuasan Pelanggan di PT. BPR Cabang Tangerang. Jurnal Mozaik, 11(1), 1825

Arikunto, S. (2012). Prosedur Penelitian Suatu Pendekatan Praktek. Jakarta: PT. Rhineka Cipta

Hasan, A. (2015). Marketing dan Kasus-Kasus Pilihan. Yogyakarta: Center for Academic Publishing Service

Kasmir, K. (2015). Ertika Customer Service. Jakarta: Raja Grafindo Persada

Kotler, P. (2013). Prinsip-Prinsip Pemasaran, Edisi 13, Jilid 1. Jakarta: Erlangga

Kotler, P., \& Armstrong, G. (2016). Prinsip-Prinsip Pemasaran, Edisi 13, Jilid 1. Jakarta: Erlangga

Kotler, P., \& Keller, K. L. (2016). Marketing Management Edisi 14. New Jersey: Pearson Pretice Hall, Inc

Lupiyoadi, R. (2013). Manajemen Pemasaran Jasa: Teori dan Praktik. Jakarta: Salemba Empat

Nurhidayati, N., \& Yuliantari, K. (2018). Analisis Pengaruh Kepuasan Pelanggan terhadap Loyalitas Pelanggan pada Fish Streat Cabang Tebet. Widya Cipta, 2(1), 69-75

Rachmawati, R. (2014). Pengaruh Kepuasan terhadap Loyalitas Pelanggan (Sebuah Kajian terhadap Bisnis Makanan). Teknobuga, 1(1), 66-79

Siregar, S. (2013). Metode Penelitian Kuantitatif. Jakarta: PT Fajar Interpratama Mandiri

Sutisna, S. (2012). Perilaku Konsumen dan Komunikasi Pemasaran, Edisis Kedua. Bandung: Remaja Rosdakarya

Tjiptono, F. (2015). Strategi Pemasaran, Edisi 4. Yogyakarta: Andi

Tjiptono, F., \& Chandra, G. (2012). Strategi Pemasaran. Yogyakarta: Andi 